\title{
Respiratory outcomes in the first ten years-of-life in children with gastroschisis: a retrospective cohort study
}

\author{
Osamuyi Asemota ${ }^{1}$, Gabrielle Derraugh ${ }^{1}$, Matthew Levesque ${ }^{1}$, Suyin Lum Min ${ }^{1}$, Shaikh \\ Iqbal $^{1}$, Robert Balshaw ${ }^{2}$, and Richard Keijzer ${ }^{1}$ \\ ${ }^{1}$ University of Manitoba Faculty of Health Sciences \\ ${ }^{2}$ University of Manitoba
}

October 26, 2020

\begin{abstract}
Background Little attention has been given to the long-term respiratory outcomes of children with gastroschisis. The purpose of this study was to determine if gastroschisis survivors have more respiratory illnesses in their first 10 years-of-life compared to age-matched controls. Methods We performed a retrospective cohort study of all gastroschisis children born in Manitoba between 1991-2017. Gastroschisis cases were identified from a clinical database, and a date-of-birth matched control cohort was constructed from a population-based data repository. International Classification of Disease codes were used to compare the risk and frequency of respiratory diagnoses for children with gastroschisis to date-of-birth matched controls from $0-5$ years-of-age and 5-10 years-of-age. Results The 0-5 years-of-age analysis included 117 gastroschisis cases and 1205 dateof-birth matched controls; children with gastroschisis had a higher risk of asthma $(\mathrm{RR}=1.46,95 \% \mathrm{CI}: 1.03,2.55, \mathrm{p}=0.029)$, acute bronchitis/bronchiolitis $(\mathrm{RR}=1.61,95 \% \mathrm{CI}: 1.27,2.03, \mathrm{p}<0.001)$, pneumonia $(\mathrm{RR}=1.99,95 \% \mathrm{CI}: 1.45,2.72, \mathrm{p}<0.001)$, viral pneumonia $(\mathrm{RR}=5.15,95 \% \mathrm{CI}: 1.79,14.81, \mathrm{p}=0.007)$, and pneumonia due to unspecified organism $(\mathrm{RR}=2.06,95 \% \mathrm{CI}: 1.45,2.92$, $\mathrm{p}<0.001)$. Gastroschisis children 0-5 years-of-age were also diagnosed more frequently with bronchitis/bronchiolitis $(\mathrm{RR}=2.14$, 95\% CI:1.79,2.57, $\mathrm{p}<0.001)$ and viral pneumonia $(\mathrm{RR}=8.10,95 \% \mathrm{CI}: 3.79,17.31, \mathrm{p}<0.001)$. The 5 -10 years-of-age analysis included 73 cases and 738 controls; no difference in the risk of respiratory illness was found for gastroschisis cases and controls in this age group. However, gastroschisis cases were more frequently diagnosed with bacterial pneumonia (RR=3.03, 95\%CI:1.67,5.51, $\mathrm{p}<0.001)$ and influenza $(\mathrm{RR}=3.03,95 \% \mathrm{CI}: 1.67,5.51, \mathrm{p}<0.001)$. Conclusion Our study shows that children with gastroschisis have an increased risk of asthma and respiratory infections compared to children without gastroschisis, especially in the first 5 years-of-life.
\end{abstract}

\section{Hosted file}

SLM 240CT2020.pdf available at https://authorea.com/users/370112/articles/488867-respiratoryoutcomes-in-the-first-ten-years-of-life-in-children-with-gastroschisis-a-retrospectivecohort-study

\section{Hosted file}

TABLES AND FIGURES submitted.pdf available at https://authorea.com/users/370112/ articles/488867-respiratory-outcomes-in-the-first-ten-years-of-life-in-children-withgastroschisis-a-retrospective-cohort-study 